\title{
Correction to: Guidelines for the management of myocardial infarction/injury with non-obstructive coronary arteries (MINOCA): a position paper from the Dutch ACS working group
}

\author{
T. F. S. Pustjens · Y. Appelman · P. Damman · J. M. ten Berg · J. W. Jukema · R. J. de Winter · W. R. P. Agema • \\ M. L. J. van der Wielen · F. Arslan · S. Rasoul · A. W. J. van 't Hof
}

Published online: 11 December 2019

(C) The Author(s) 2019

\section{Correction to:}

Neth Heart J 2019

https://doi.org/10.1007/s12471-019-01344-6

The reference to the term acute coronary syndrome with normal or near-normal (non-obstructive) coronary arteries (ACSNNOCA) from Manolis et al. (2018) was inadvertently omitted to the original published article. Therefore, the following reference should be added to our paper:

- Manolis AS, Manolis AA, Manolis TA, Melita H. Acute coronary syndromes in patients with angiographically normal or near normal (non-obstructive) coronary arteries. Trends Cardiovasc Med. 2018;28(8):541-51. https://doi.org/10.1016/j.tcm. 2018.05.006.
The authors would like to apologise for any inconvenience caused.

Open Access This article is licensed under a Creative Commons Attribution 4.0 International License, which permits use, sharing, adaptation, distribution and reproduction in any medium or format, as long as you give appropriate credit to the original author(s) and the source, provide a link to the Creative Commons licence, and indicate if changes were made. The images or other third party material in this article are included in the article's Creative Commons licence, unless indicated otherwise in a credit line to the material. If material is not included in the article's Creative Commons licence and your intended use is not permitted by statutory regulation or exceeds the permitted use, you will need to obtain permission directly from the copyright holder. To view a copy of this licence, visit http://creativecommons. org/licenses/by/4.0/.
The online version of the original article can be found under https://doi.org/10.1007/s12471-019-01344-6.

T. F. S. Pustjens $(\bowtie) \cdot$ S. Rasoul · A. W. J. van 't Hof Department of Cardiology, Zuyderland Medical Centre, Heerlen, The Netherlands

t.pustjens@gmail.com

\section{Y. Appelman}

Department of Cardiology, location VU University Medical

Centre, Amsterdam UMC, Amsterdam, The Netherlands

\section{P. Damman}

Department of Cardiology, Radboud University Medical Centre, Nijmegen, The Netherlands

\section{J. M. ten Berg · F. Arslan}

Department of Cardiology, St Antonius Hospital,

Nieuwegein, The Netherlands

\section{J. W. Jukema}

Department of Cardiology, Leiden University Medical

Centre, Leiden, The Netherlands

\section{R. J. de Winter}

Department of Cardiology, location Academic Medical Centre, Amsterdam UMC, Amsterdam, The Netherlands

\section{W. R. P. Agema}

Department of Cardiology, Jeroen Bosch Hospital, 's-Hertogenbosch, The Netherlands

\section{L. J. van der Wielen}

Department of Cardiology, location Bethesda, Treant Zorggroep, Hoogeveen, The Netherlands

S. Rasoul · A. W. J. van 't Hof

Department of Cardiology, Maastricht University Medical Centre, Maastricht, The Netherlands

A. W. J. van't Hof

Department of Cardiology, Isala Hospital, Zwolle, The Netherlands 